\title{
O USO DA HISTÓRIA DA MATEMÁTICA POR PROFESSORES NO ENSINO FUNDAMENTAL
}

\author{
Matheus Marques de Araújo, Universidade Federal de Campina Grande (UFCG), \\ marquesmatheusaraujo@gmail.com \\ Gardênia Pereira Brito, Universidade Federal de Campina Grande (UFCG), \\ gardeniapereira18@gmail.com \\ Rosinângela Cavalcanti da Silva, Universidade Federal de Campina Grande (UFCG), \\ professorarosinangela@gmail.com
}

PALAVRAS-CHAVE: História da Matemática; Processo Ensino-aprendizagem; Ensino Fundamental.

\section{INTRODUÇÃO}

O uso da História da Matemática em sala de aula se apresenta como um auxílio pedagógico de grande importância e seu uso nas aulas de matemática não é, essencialmente, uma novidade entre os professores de Matemática. Desde a década de 90, existe uma ampliação da presença do contexto histórico nos livros didáticos. Atualmente é preciso reconhecer que cada estudante desenvolve suas atividades em uma sociedade globalizada, no qual o raciocínio lógico é requisito fundamental para uma participação ativa e crítica, dessa forma, são necessárias algumas mudanças na atividade docente. Sob tal enfoque, foi realizada uma pesquisa com os professores do ensino fundamental, sobre o uso da História da Matemática como recurso metodológico. É notório que grande parte dos educadores concordam que o uso da História da Matemática deve estar presente durante o estudo dos conteúdos, deste modo, a abordagem da História da Matemática e sua interpretação podem ser vistas como indispensáveis à Educação Matemática.

\section{METODOLOGIA}

Este trabalho é resultado das atividades desenvolvidas no Projeto de Extensão: História da Matemática como recurso metodológico, que teve como objetivo reconhecer a importância da História da Matemática para um ensino significativo e motivador e mostrar a importância de envolver o estudo da História da Matemática junto aos conteúdos abordados 
em sala de aula e assim dar sentido ao assunto estudado, despertar nos professores e futuros professores o interesse na busca de novas metodologias de trabalho, capacitar os alunos do curso de Licenciatura em Matemática, do Centro de Formação de Professores da Universidade Federal de Campina Grande para o trabalho com a história da Matemática em sala de aula, analisar os livros didáticos adotados pelas escolas usando o critério da presença da História da Matemática, ajudando nas novas escolhas dos livros didáticos, fortalecer o trabalho docente das escolas públicas em busca de uma educação de qualidade e significativa, buscar uma melhor formação docente para os alunos licenciandos em Matemática.

Com esse intuito, foi feito um levantamento nas Escolas estaduais e Municipais das cidades de Cajazeiras, Sousa e Aparecida com o propósito de investigar se os professores de Matemática conhecem a História da Matemática, se utilizam essa metodologia em suas aulas e se fazem relação entre os conteúdos matemáticos e o contexto histórico em que foram estudados. E também, analisar os livros didáticos adotados pelos professores investigando a presença ou não da História da Matemática nos conteúdos abordados nos livros.

\title{
3 RESULTADOS
}

Grandes educadores matemáticos concordam que o uso da História da Matemática deve estar presente durante a exposição e abordagem dos conteúdos. Conforme D’ Ambrósio (1996, p. 13),

\begin{abstract}
É importante dizer que não é necessário que o professor seja um especialista para introduzir História da Matemática em seus cursos. Se em algum tema o professor tem uma informação ou sabe de uma curiosidade histórica, deve compartilhar com os alunos. Se sobre outro tem ele não tem o que falar, não importa. Não é necessário desenvolver um currículo, linear e organizado de História da Matemática. Basta colocar aqui e ali algumas reflexões. Isso pode gerar muito interesse nas aulas de Matemática. E isso pode ser feito sem que o professor tenha se especializado em História da Matemática.
\end{abstract}

De acordo com D’ Ambrósio (1996), a História da Matemática no ensino deve ser vista especialmente, pelo seu valor de motivação. Assim, através da História, os professores realizam atividades que motivam os seus alunos a terem interesse em descobrir como os matemáticos chegaram às definições e compreensão dos conteúdos matemáticos. Além disso, segundo D’ Ambrósio (1996), jamais se deve deixar transparecer a impressão por meio de um 
desfilar de nomes, datas, resultados, casos, fatos, que se está ensinando a origem de resultados e teorias Matemáticas, uma vez que, é necessário entender e destacar as origens da Matemática. Muitos professores tem a errônea ideia de que trabalhar a História da Matemática é apenas ler rapidamente um texto de estudo em sala de aula. Muito pelo contrário, trabalhar História da Matemática é dar sentido ao que se está sendo estudado, mostrando ao aluno que os conteúdos matemáticos têm fundamentos e diversas aplicações no dia-dia, dando sentido as aulas de Matemática.

Através do questionário aplicado aos professores de Matemática do Ensino Fundamental, pode-se concluir que os professores das instituições conhecem a História da Matemática, e apesar de achá-la importante, nem sempre acham necessário expor este recurso na sala de aula. Os alunos têm interesse em saber a História da Matemática, porém os professores justificam que a instituição não fornece recursos que ajudem a expor esse contexto na sala de aula.

Os professores afirmaram que encontram dificuldades em encontrar a abordagem da História da Matemática no livro didático adotado pela escola, e que quando precisam usam a internet ou outra coleção para pesquisar sobre a história. Os professores consideram necessário introduzir a História da Matemática nas aulas, porém sempre culpam a estrutura da escola e os livros didáticos, de não abordarem os conteúdos neste contexto.

As escolas onde foram aplicados os questionários adotam junto aos professores três coleções de livros didáticos para uso durante o exercício da docência. Por meio da análise destes, pode-se perceber que as três coleções abordam tópicos que ligam o conteúdo a História da Matemática, apesar de não ser dada ênfase da mesma forma. Assim, os professores embora muitas vezes justifiquem a falta de acesso ao contexto histórico dos conteúdos e aplicação deles durante as aulas, têm sim oportunidades de trabalhar a História da Matemática em sala, na verdade o que acontece é um receio de que a abordagem histórica dos conteúdos atrapalhe o desenvolvimento da aula e assim exista uma perca de tempo e atraso no cronograma de atividades. D’Ambrósio (1996. p.13) afirma:

Esses professores estarão se perguntando: mas como lidar com isso (o autor se refere à história da Matemática) na minha prática como professor de Matemática? E ele responde: sei que muitos estão pensando que não vai sobrar tempo para darmos conteúdo de Matemática se gastarmos tempo falando sobre Matemática. Pois eu digo que a solução é cortar conteúdos, retirando coisas chatas, obsoletas inúteis (...) procure, para cada tema do que sobrou nos programas atuais, uma justificativa autêntica de porque o tal tema deve ser ensinado e exigido a todos. E vocês 
chegarão à conclusão de que muito do que se ensina está lá por valor histórico. Por que então não assumirmos e darmos a Matemática que integra currículos sua verdadeira cara, fazendo um estudo crítico no seu contexto histórico? Sem dúvida pode ser mais atrativo.

Os parâmetros curriculares surgem da necessidade de atualizar o ensino, buscando seguir a evolução tecnológica e social. Seguindo as recomendações dos PCN's, em 2004 o governo implantou o Programa Nacional do Livro Didático (PNLD). As ideias presentes nos parâmetros curriculares nacionais em matemática expressam muito mais do que mudanças no ensino e aprendizagem de matemática, refletem a necessidade de mudanças no que se ensinar e como ensinar, deixando claro que o professor precisa buscar novas alternativas que solucionem o déficit de aprendizagem em matemática. Portanto a abordagem da história da matemática durante as aulas se mostra como um bom recurso metodológico para a compreensão e desmistificação dos assuntos que estão sendo abordados.

\section{CONSIDERAÇÕES FINAIS}

Nos dias atuais, mediante as dificuldades encontradas na sala de aula, é de extrema importância utilizar a História da Matemática nas aulas, pois dessa forma os alunos irão conseguir ter um contato maior com a disciplina e vão conseguir compreender as origens dos conteúdos trabalhados.

Expondo o contexto histórico no qual os conteúdos foram estudados ao longo da evolução humana, o professor consegue desmistificar a Matemática e consegue fazer com que o aluno perceba que a Matemática que estudamos hoje percorreu um longo caminho da história da humanidade, passando por várias fases.

Percebe-se que os professores reconhecem a importância da História da Matemática, porém ainda não a utilizam como recurso metodológico em suas aulas, optando por suas rotinas, ainda rejeitando as inovações. Alguns se justificam pela falta de motivação com o ensino e a turma, e acabam afastando o aluno da disciplina e fazendo com que os mesmos acreditem que a Matemática não passa da efetuação de cálculos. Segundo eles, trabalhar o recurso histórico como metodologia de ensino é um fardo, pois aumenta seu trabalho. Além disso, acreditam que a falta de tempo somado a falta de recursos, é o que os impossibilitam de trabalhar atividades diferenciadas com os alunos. 
Não há regras para a abordagem da História da Matemática, podendo ser aplicada e abordada de diferentes formas pelos docentes, cada educador pode e deve utilizar este recurso no momento mais adequado. A abordagem da História da Matemática na aula pode deixar as aulas mais agradáveis, criativas, além de enriquecer e proporcionar a interdisciplinaridade, motivando o aluno a tomar gosto pelo estudo da Matemática, despertando a curiosidade e o espírito investigativo, cabe ao professor pesquisar e utilizar esse recurso metodológico da maneira que lhe for mais conveniente.

\section{REFERÊNCIAS}

D’AMBROSIO, U. História da Matemática e Educação. In: Cadernos CEDES 40. História e Educação Matemática. $1^{a}$ ed. Campinas, SP: Papirus, 1996.

Brasil. Ministério da Educação e do Desporto. Secretaria de Educação Fundamental. Parâmetros Curriculares Nacionais (Ensino Fundamental) Matemática. Brasília: Mec, 2004. Disponível em. Acesso: 18 out. 2006. 